\title{
A modified azoalbumin technique for the assay of proteolytic enzymes for use in blood group serology
}

\author{
PK PHILLIPS, DILYS PRIOR, B DAWES \\ From the Blood Group Reference Laboratory, Oxford
}

SUMMARY A spectrophotometric assay of proteolytic enzyme activity is described in which the optical density obtained by a given enzyme preparation is related $(2 \propto<0.01)$ to the serological activity of that preparation in a two stage technique. The assay appears to be of use for the standardisation of enzyme preparations for use in blood group serology.

In contrast to most other reagents used in blood group serology, proteolytic enzyme solutions are frequently prepared by individual users. Procedures for the standardisation of these products are, however, not well established. A spectrophotometric technique for the assay of protease activity using azoalbumin has previously been reported. ${ }^{1}$ In our hands this assay lacked sensitivity. The assay was modified in order to improve the sensitivity and a study was then undertaken to reassess the value of the assay in the standardisation of proteolytic enzyme preparations for use in a two-stage serological technique.

\section{Material and methods}

\section{ENZYME PREPARATIONS}

Seventeen enzyme preparations were obtained from 11 different commercial suppliers: seven powder papain preparations, four powder bromelain preparations, two liquid papain preparations, one freeze-dried preparation of papain and three freeze-dried preparations of bromelain. From each powder preparation, $10 \mathrm{~g} / \mathrm{l}$ solution was prepared in $0.067 \mathrm{M}$ phosphate buffer, $\mathrm{pH} 5.4$, with $0.5 \mathrm{M}$ l-cysteine, by the method of Löw. ${ }^{2}$ Liquid preparations were used as provided. Freeze-dried preparations were reconstituted according to manufacturers' instructions. All preparations were tested within the manufacturers' stated periods of use.

\section{ENZYME TREATMENT OF RED CELLS}

Nine volumes of a $3 \%$ suspension of washed red

Accepted for publication 22 November 1983 cells in $0 \cdot 15 \mathrm{M} \mathrm{NaCl}$ (saline) were incubated with one volume of enzyme preparation at $37^{\circ} \mathrm{C}$ for 10 $\mathrm{min}$. The red cells were washed three times in saline and resuspended to a $3 \%$ suspension.

\section{ANTISERA AND SEROLOGICAL TECHNIQUES}

Seven antisera were used: anti- $D$, anti-c(2), anti-e, anti-k, anti-Ce and anti-Wr(a). All antisera contained incomplete antibodies which failed to agglutinate cells suspended in saline. One ml doubling dilutions from $1 / 1$ to $1 / 512$ in saline were prepared of each antiserum and 17 identical sets of dilutions were prepared from these master dilutions. Each set was tested as described below with the appropriate red cells pretreated with a different enzyme preparation. One volume $(30 \mu \mathrm{l})$ antiserum dilution was mixed and incubated with one volume of a $3 \%$ suspension of enzyme treated cells for one hour at $37^{\circ} \mathrm{C}$. The cell buttons were transferred to a glass slide. The results were read macroscopically and microscopically and the strengths of reaction were scored on a scale from 0-7. All serological tests were performed on the same day for each antiserum. As a negative control, a normal human serum, free of any unexpected blood group antibodies, was incubated with each enzyme treated red cell preparation.

\section{AZOALBUMIN ASSAY}

One hundred microlitres of enzyme preparation were added to $1 \mathrm{ml}$ of azoalbumin (Sigma) $20 \mathrm{mg} / \mathrm{ml}$

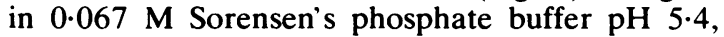
mixed and incubated at $37^{\circ} \mathrm{C}$ for $30 \mathrm{~min}$. One $\mathrm{ml}$ of $50 \mathrm{~g} / \mathrm{l}$ trichloroacetic acid was added and the reaction mixture centrifuged at $1000 \mathrm{~g}$ for $5 \mathrm{~min}$. One $\mathrm{ml}$ of supernatant was added to $1 \mathrm{ml}$ of $0.5 \mathrm{M}$ 
Table 1 Mean titration scores obtained by the normal serum and by the seven antisera, mean optical densities in azoalbumin assays and corresponding ranked values for each enzyme preparation

\begin{tabular}{|c|c|c|c|c|c|c|}
\hline \multirow{2}{*}{$\begin{array}{l}\text { Enzyme } \\
\text { preparation }\end{array}$} & \multicolumn{2}{|c|}{ Reaction of cells with normal serum } & \multicolumn{2}{|c|}{ Reaction of cells with the antisera } & \multirow{2}{*}{$\begin{array}{l}\text { Assay optical } \\
\text { density }\end{array}$} & \multirow{2}{*}{$\begin{array}{l}\text { Rank of optical } \\
\text { density }\end{array}$} \\
\hline & Mean score & $\begin{array}{l}\text { Rank of normal } \\
\text { mean score }\end{array}$ & Mean score & Rank of mean score & & \\
\hline 1 & 0.4 & 4 & $27 \cdot 1$ & 1 & $1.50 \times 2^{*}$ & 1 \\
\hline 2 & 0.9 & 1 & $23 \cdot 1$ & 4 & 1.63 & 5 \\
\hline 3 & 0 & $15 \cdot 5$ & $22 \cdot 0$ & 5 & $1 \cdot 33$ & 10 \\
\hline 4 & $0 \cdot 1$ & 11 & $18 \cdot 7$ & 12 & 0.93 & 12 \\
\hline 5 & 0 & $15 \cdot 5$ & $19 \cdot 3$ & 10 & $1 \cdot 33$ & 9 \\
\hline 6 & $0 \cdot 6$ & 2 & $19 \cdot 1$ & 11 & 0.97 & 11 \\
\hline 7 & $0 \cdot 1$ & 11 & $24 \cdot 9$ & 2 & $1 \cdot 71$ & 4 \\
\hline 8 & 0.4 & 4 & $20 \cdot 9$ & 7 & $1 \cdot 18$ & 13 \\
\hline 9 & $0 \cdot 1$ & 11 & $20 \cdot 0$ & $8 \cdot 5$ & 1.47 & 7 \\
\hline 10 & 0.3 & 7 & $18 \cdot 6$ & 13 & 0.75 & 14 \\
\hline 11 & $0 \cdot 1$ & 11 & $12 \cdot 4$ & 15 & 0.23 & 16 \\
\hline 12 & 0 & $15 \cdot 5$ & $11 \cdot 3$ & 16 & 0.12 & 17 \\
\hline 13 & $0 \cdot 3$ & 7 & $11 \cdot 0$ & 17 & 0.25 & 15 \\
\hline 14 & $0 \cdot 4$ & 4 & $20 \cdot 0$ & $8 \cdot 5$ & 1.44 & 8 \\
\hline 15 & $0 \cdot 1$ & 11 & $17 \cdot 4$ & 14 & $1 \cdot 86$ & 3 \\
\hline 16 & 0 & $15 \cdot 5$ & $21 \cdot 7$ & 6 & $1 \cdot 52$ & 6 \\
\hline 17 & $0 \cdot 3$ & 7 & $24 \cdot 4$ & 3 & $1.14 \times 2^{*}$ & 2 \\
\hline
\end{tabular}

*These two preparations were of such activity that an initial $1 / 2$ dilution was required for assay to obtain these values.

$\mathrm{NaOH}$. The optical density was determined at 440 $\mathrm{nm}$ against a reagent control obtained by incubating the azoalbumin preparation with phosphate buffer $\mathrm{pH} 5 \cdot 4$, in the absence of enzyme. Azoalbumin assays were performed together on the same day in duplicate.

\section{Results}

The azoalbumin method as employed for the assessment of proteolytic enzyme preparations used

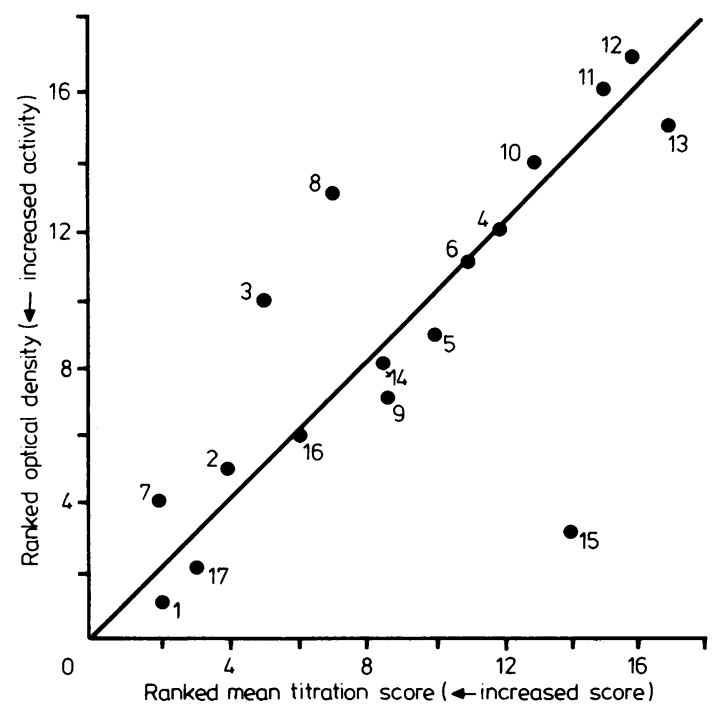

Fig Relation between ranked assay optical density and ranked mean titration score. in blood group serology ${ }^{1}$ was developed from an assay of peptic and tryptic activity ${ }^{4}$ and employs a $\mathrm{pH}$ of $6 \cdot 5$. However, for use in blood group serology papain is usually prepared at $\mathrm{pH} 5.4-5.6$ by the method of Löw. ${ }^{2}$ Other modifications in the present assay procedure included the use of a smaller total reaction volume with proportionally more of the enzyme preparation. The optical densities obtained in the azoalbumin assays at $\mathrm{pH} 6.5$ and at $\mathrm{pH} 5.4$ were very different. One enzyme preparation gave an optical density of 0.02 when assayed at $\mathrm{pH} 6.5$ by the technique of Lambert et al ${ }^{1}$ but of 0.8 at $\mathrm{pH} 5.4$ with the modified assay. No deterioration was detected in the azoalbumin stored at $-20^{\circ} \mathrm{C}$ for one month and the reagent was also stable at $37^{\circ} \mathrm{C}$ over a working day. From 21 independent estimations of a single preparation of papain a $95 \%$ reproducibility of $\pm 7.4 \%$ and a coefficient of variation of $\pm 3.5 \%$ were obtained.

In Table 1 the mean score for the reactions of the normal serum with enzyme-treated cells, the mean score for the reactions of the seven antisera with the same cells and the mean of the optical densities obtained in duplicate azoalbumin assays, are given for each enzyme preparation together with their corresponding ranked values. A wide variation in reactivity was obtained with the 17 enzyme preparations with respect to serological activity and to values in the azoalbumin assay. Two very active enzyme preparations, Nos 1 and 17 , required to be diluted $1 / 2$ before assay. Three preparations, Nos 11,12 and 13, of which two were presented as freeze-dried preparations and one as a liquid preparation, emerged clearly as the least satisfactory both serologically and by assay. 
The ranked optical densities and ranked mean titration scores of the seven antisera were significantly related (Spearman's rank correlation coefficient $=$ $0 \cdot 76$, that is $0.001<2 x<0.01) .^{3}$ The relation is shown graphically in the Figure. There was no significant relation between ranked optical densities and the ranked scores of the normal serum (coefficient $=0 \cdot 19,2 \times>0 \cdot 10$ ). There was no relation between the ranked scores for the normal serum and the ranked mean scores with the seven antisera.

\section{Discussion}

Proteolytic enzymes, in particular papain and bromelain, are widely used for the detection of antibodies to red cell antigens. Recent surveys undertaken as part of the UK National External Quality Assessment Scheme (NEQAS) in blood group serology indicate that the use of enzymes in compatibility testing is increasing although the enzyme crossmatch technique is the least reliable for the detection of incomplete blood group antibodies. ${ }^{5}$

The NEQAS surveys revealed that enzyme preparations are obtained from many different sources and that working enzyme solutions may be prepared within the users' laboratories $(25 \%)$, by Regional Transfusion Centres (36\%) or by commercial suppliers $(39 \%) .^{5}$ While some commercial suppliers provide working enzyme preparations ready-for-use as liquid "stabilised" enzyme preparations or as freeze-dried material for reconstitution, the majority of working enzyme solutions are prepared from crude powder extracts in hospitals or Regional Transfusion Centres. However, few practical methods are available for standardisation of such preparations. Enzyme solutions are usually assessed serologically but, in the absence of suitable reference preparations, this approach is unlikely to be reliable.

The results obtained using the azoalbumin technique were very similar to those obtained serologically. In that respect little was gained but the azoalbumin technique has considerable advantages in precision and ease of performance. It was not clear from the spread of the mean agglutination scores obtained by the seventeen enzyme preparations if any of the preparations gave optimal agglutination reactions. A limiting factor for the potency of enzyme preparations is their propensity to give rise to "false positive" results - that is, agglutination of cells in the presence of normal serum which is free of any antibody. In the present study there was no evidence that the most potent preparations gave higher agglutination scores with the normal serum than the weaker enzyme preparations.

In its present state of development the azoalbumin assay can only determine the relative potencies of enzyme preparations. This may be of value to manufacturers of enzyme preparations in selection of raw material, but is of limited value in the assessment of individual preparations at the user level. It would clearly be useful to develop the azoalbumin assay to obtain quantitative expressions of enzyme potency, to determine the optimal range of enzyme concentration and to develop stable reference preparations which could define minimum requirements for producers and users alike.

We are grateful to Dr AM Holburn for advice and encouragement.

\footnotetext{
References

' Lambert R, Edwards J, Anstee DJ. A simple method for the standardisation of proteolytic enzymes used in blood group serology. Med Lab Sci 1978;35:233-8.

${ }^{2}$ Löw B. A practical method using papain and incomplete Rhantibodies in routine $\mathrm{Rh}$ blood-grouping. Vox Sang (OS) 1955;5:94.

${ }^{3}$ Diem K, Lentner C, eds. Documenta Geigy. Scientific Tables. 7th ed. Basle, Switzerland: Ciba-Geigy, 1970.

${ }^{4}$ Charney J, Harding ML, Tomarelli RM. The use of azoalbumin as a substrate in the colorimetric determination of peptic and tryptic activity. J Lab Clin Med 1949;34:428-33.

${ }^{5}$ Holburn AM, Prior Dilys. The UK National External Quality Assessment Scheme. Compatibility Testing 1981-82: performance and practices. (in preparation).
}

Requests for reprints to: Dr PK Phillips, Blood Group Reference Laboratory, Harkness Building, Radcliffe Infirmary, Woodstock Road, Oxford OX2 6HE, England. 